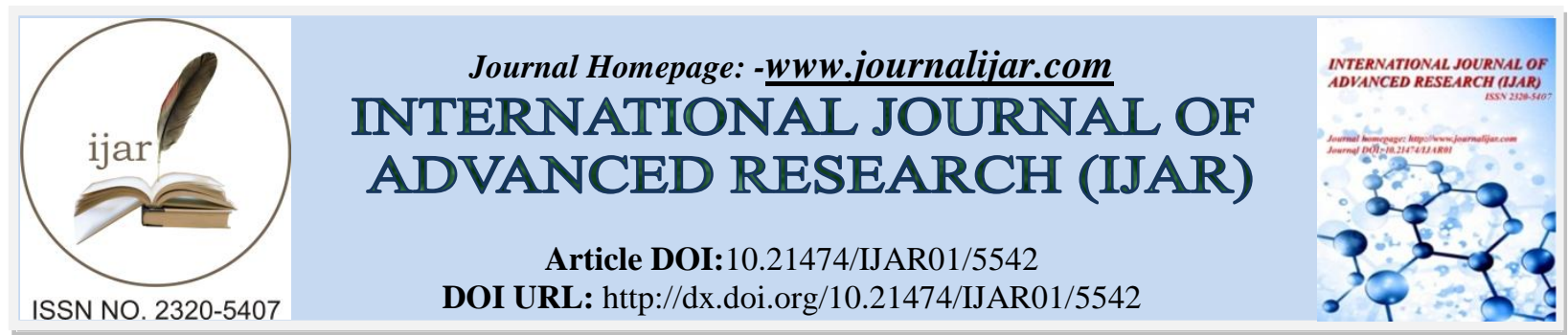

RESEARCH ARTICLE

\title{
THE INNER ENEMIES AND THE WAY OF CONTROL.
}

\section{Sanjib Kundu ${ }^{1}$ and Soumen Ganguly ${ }^{2}$.}

1. Bachelor of Visual Art from Govt. collage of Art \& Craft - Kolkata / Art \& Craft Teacher in West Bengal Govt. P.T.T.I., India.

2. M. A .in English, B.Ed. / Assistant Teacher in Burdwan Municipal High School, Burdwan, W. B. / India.

\section{Manuscript Info}

Manuscript History

Received: 05 August 2017

Final Accepted: 07 September 2017

Published: October 2017

\begin{abstract}
From the very outset of the creation of human some innate qualities have made him the lord of creative are his emotions, feelings, consciousness, joys-sorrows, doubts-hesitation, overwhelming states. Besides these six special enemies (inherent vices) have influenced him throughout his life direct or indirectly. These six characteristics are lust, anger, greed, infatuation, vanity and envy. Their mysterious outbreak have made our life with their various features. From its outcome our life, society and states, ever the whole world have been influenced for a time being and facing its consequences. The outbreak of six enemies can be detrimental to human's positive thoughts indirectly. If it is identified as a substantiated truth - then my humble request to the deadly indifferent destructive world of 21 st century is - to invent some scientific skills to dominate the outbreak of the inner enemies. And my appeal and prayer to the all forms of scientific research scholar is - not to be engrossed in any other inventions - to control the outbreak of all the six inner enemies (lust, anger, greed, infatuation, vanity and envy) or take its prevalence to a certain limit (by side-effect-less medicine, vaccination, meditation or yoga) from the coma state of the world - free the earth from the deadly nuclear weapons, terrorist, global warming, communalism, transgression to make the world heavenly by swearing with our honest intentions. We are becoming aimless to find the secret-key to make the world free from various problems - my feeling and imagination are helping me to get the secret-key. I am showing my audacity in this respect without having a conventional scientific qualification only to make the world as a welfare state. Our present civilization is in great crisis for the outbreak of the six enemies. It is the burning need to control the outbreak of the six enemies. I think that the meditation or medication can control this type of outbreak. If my innovation helps the future world to become fear-free and nice, I think I am successful - otherwise apologetic.
\end{abstract}

Copy Right, IJAR, 2017,. All rights reserved.

Corresponding Author:-SanjibKundu.

Address:-Bachelor of Visual Art from Govt. collage of Art \& Craft - Kolkata / Art \& Craft

Teacher in West Bengal Govt. P.T.T.I. , India 


\section{Introduction:-}

The mystery of the creation of the universe is being sought, the new invention of nuclear power has been done, the search for huge cosmic elements is going on with great force in the human world. Still thinking, why are we not thinking about the enemies (six inherent vices - lust, anger, greed, infatuation, vanity, envy) at large sitting inside the nook of our mind in spite of our various inventions? It is pushing us into the verge of the extreme void for his quest for aimless inventions. It is hard to calculate - how this urge for invention is sending them towards the vast void ! Yet I have become so much curious considering the innate enemy like six vices, have made us aimless and addicted, have made our judiciousness in the condition of 'coma', why are we not considering towards our strategic discoveries to control our enemies of six vices ! I shall search for it all along my life span. According to me, all the inherent enemies are responsible for all the ups and downs and extreme vacillating position. And I also think that our first target should be to invent the strategies to control the inherent enemies of our mind. If you agree with us then my earnest request is to stand by me, I want to tell it in detail :

Six enemies - lust, anger, greed, infatuation, vanity and envy are our inherent enemies. Various people of the world are now in a fix for the outbreak of the enemies. This aimless position has now turned into a mass hysteria. It has become hard to maintain the balance about our judgment about right and wrong, suitable and unsuitable. I am felling that I have to go to the root of the problem to find any remedy to get out of this miserable position. We need an invention scientifically about its proper treatment, that can dominate our enemies. Yoga or meditation was a proper path. But there is a halt to it to make it universal and as a regular exercise. So we are forced to think - how can we control the enemies by vaccination at the birth of humans in long terms. Otherwise we cannot prevent the problems what is being done endlessly throughout the world.

So we have no time to think about - this is a great crisis for the world as well as the humans. So we have to think to get rid of this and by identifying all the inner enemies we have to try to kill them. For this crisis the mostly responsible things are our inherent sins of our body - the prevalence of lust, anger, greed, infatuation, vanity and envy. For this various demerits of our body like impatience, lack of endurance, recklessness, lack of co-operative attitude, introversion, cowardice. Human are moving towards the grave erosion of values for the lack of respect, honesty, humility, patience, endurance and devotion. Regular yoga or meditation and physical exercise were the two important aspects to control and adopt it. But in the whole world we are watching the lack of practice of this yoga or meditation and physical exercise. So the lack of yoga or meditation and exercise makes the world a terrible place. A suitable personality wouldhave been grown if children were nurtured in their childhood in a balanced way as the skillful system of children grooming. It is not always possible to form a skillful personality as the intelligence and the development of a child's aspects are not always comprehensible to the guardians. The lack of knowledge is watched in the aspects of grooming a child all over the world, in this side we need some scientific training about the upbringing of a child even before the women conceive a child. For this the world is becoming immature.

It is a matter of frustration - for the invention of nuclear power, for its misuse, our terrible outlook in using our lust, aggression, temptation and anger - it seems to us that the impact of all the positive thinking's are becoming feeble for the implementation of our negative thoughts. Now it is a matter of secret pride to a nation to buy a devastating nuclear weapon, deadly weapon or war craft or its invention or its collection. The states which invent or collect them express their opinion or mentality in such a way - 'None can imagine how we will use our possession'! In reality if it is a negative opinion or even it is a positive opinion for argument - but to all the countries of the world this opinion is being felt as a positive (wrongly). Here lies the problem. The nurture and the invention of the nuclear power can never be beneficial to mankind. Though we are feeling it but we cannot maintain its dignity and becoming helpless to the situation. There are various causes and effects of it but the prevalence of six enemies are responsible for it for this helpless situation and result. The political leaders of the world are feeling the conflict of it. All the six sins are prevailing all over it.

It is quite common that a terrible terrorism is growing up all over the world. Various ignorance and orthodox ideas have cast their evil shadows all over the world over the exploited class depriving them from all sorts of lights of education. We have formed a class discrimination using superstitions by our arrogant governance, to save our smaller interest for our poor mentality, the persons who become terrible terrorists out of frustration and it is quite common because they are only the victims of deprivation our only concern is to how to control them ! Revenge is not way. We could have stopped it with non-violence but the prolonged violence would easily destroy them in the mean time. Generally we will find no way to stop it. 
For our fast life style we are facing the terrible impact for the spread of pollution and carbon. The world tells silently for the lack of forest - "How much oxygen can we give ? I am parched with carbon - my body is dead." So we have to think, how much resources do we need ? Why our need have increased ? We were happy with nominal things. What will be the benefit in this risky game, if for our competition there is total upset in the world system. We are not coming into the consensus in the world climatic conferences. Developed countries do not obey the law of carbon emission as it will curtail their honor. The world is indifferent about the global warming. The mean sea level is increasing. The polar ices are melting. The condensation is becoming hard for the melting point of lustend temptation. The prevalence of six enemies - lust, anger, greed, infatuation, vanity and envy are responsible for it. None can stop this huge destructive force. We are now busy with our ridiculous efforts with our 'seeming live' state after destroying the world with her living forces.

Some social dishonesty, easy temptation, recklessness, lusty attitude, deception, doubt, laziness, inertia, deadly diseases, bacterial infections are increasing in different styles. Our unwanted food habit and lifestyle have made us like a wild beast. We are not fond of plain and simple food. We are much more interested in the taste of tongue than the proper development of our body. So we are becoming mad with the intake of low quality food out of infatuation. Food habits can influence the mankind's behavior and so our behavior is becoming reckless. Positive and flexible mentalities are nominal to such recklessness. So we do not know how long it will take to bring mankind in the main stream of their life. Again the vagaries of nature have disrupted our life. Flood, drought, earthquake, increase of temperature, cyclone have become nightmare. All these are results of our long term recklessness. Do we have any time to be interested in detail ? If we have any solution, who will obey it ! We have to go beyond it. Our scientific outlook and utmost effort to survive will show a new way from 'hell tormented'.

Now sitting on the apex of the hill of erosions, driven by the tragic anger and repentance, my aesthetic senses are trying to create various creative works, at the same time I want to finish the much necessary words - so leaving the art I have taken the pen. I have thought much - seen various noble efforts - how many people are trying to build up the world with so much sincerity, noble heart as a creative form. Buddhist monks, Sikhs, Jainas, Hindus, Muslims, Christians are trying to make the world as a peaceful place with their noble efforts. It is going on endlessly. All the beneficial forces of the world as busy in devoting their times in worshipping God with the thought of igniting the massive inner thoughts. The directives of this emancipation are written in the 'Vedas', 'Vedanta' and 'Upanishad' (The core spiritual philosophies of Hinduism) and many noble souls have cast their influences about the salvation of mankind through their spirits igniting the inner spirits of us. Ever now "PrajapitaBrahamaKumarisIshwariyaVishwaVidyalaya" (A spiritual foundation in India) followers are endlessly striving to create a heavenly atmosphere by preaching the thoughts of humanism. They are forming a concept of 'Supreme soul' by imbibing the 'Rajyog' meditation, with the addition of spiritual concept. It is an extraordinary thing that the great philosophers are doing through an easy way by their power of concentration for the formless cosmic point super soul, i.e. "Shiva"(The principal deities of Hinduism) end supreme power or thinking with utmost patience by deactivating the inner enemies. It is my belief that one day we will form such a heavenly delight through this path. I have profound respect over their deeds and positive efforts. By following this path mankind will surely find a way out from huge frustration, miseries and confusion. Another saint of India -"Swami Vivekananda" (An Indian Hindu monk) told us about his philosophy in his books 'Rajyog', 'Gyanyog' and 'Karmayog' about the temptation and the way to get rid of it. Our emancipation will increase as long as his humorist, sacrifice, concentration, inner spirits, characteristics will be discussed throughout the world. We have to remember more about the 'Supreme power' regularly for kindling the self rectification and positive forces. Then we can realize the presence of the supreme entity inside our soul, we can realize the heavenly beauty of the earth : where lies the blue sky, birds flying in it, rows of green forests, colors of herbs \& climbers, flourishing flowers \& leaves, sounds of human activities all around, lonely field, serpentine rivers, waves, open fields of grains, rising sun, setting sun, deep dark night, enchanting full moon night - Do we stand for some time to watch this beautiful things of the earth ? There was meditation in this sight, yoga in this sight, get rid of the problem, feeling of external peace, proximity to godliness. This proximity is a great treasure to me. This philosophy has beautified my inner world, has satisfied my soul. I am full to the brim in my life. I want to know if all are getting the same amount of delight. It does not happen to all. Day by day our inner power is tied with indifference, lust, fame, influences of temptation and we are becoming more aggressive animals as the knot is becoming tight. As I have not found any alternative - trying to find such a new medicine that will help a misbalanced society in to a balanced form. So being a small creature, I will try my level best to save the world from all the clutches of the evil forces as the famous poet 'Rabindranath Tagore' said 
..." Who will take up my work, said the setting sun

Hearing this all the world remained silent

The earthen lamp, told to the lord

I will try to do, as much as I can "...

I have done to bring the man out of the clutches of the indifference, seems not a reliable at now, but none can throw it at all. It may be acceptable to the coming world. I do not know how long the world can last as the cruel end harsh lust are increasing day by day. In this time of crisis I have some earnest requests and proposals to the all types of researchers of the world:

\section{Proposal:-}

By self mending, relying on will force and mass awareness we can get rid of the inner enemies in the natural way. But the prevalence of all the inner enemies are taking the world to a crisis and are probably the effect of oversecretion of various chemicals. (I am neither a scientist nor a philosopher - but an Artist. Feelings \& imaginations are my assistance. I know that I can solely solve the problem. The matter is totally dependent on medical science \& psychology. But going deep into the creativity and fine arts, we can enter into the compound of the other researches. Curious mind can sometimes show its influence while selecting the subject. It seems that art has its liberty and it also comes from earnest sincerity). While thinking much about the various aspects of arts, I have delved deep into the activities of the world and its causes \& I havecome to the conclusion that our problem is at the root. The recklessness of the desires in our heart are the outcome of our inner enemies' madness. The over secretion of the hormones or the prevalence of them may lead to a reckless and luxurious lifestyle. If we can control them we can change our characteristics and the society and the world.

Again it may prove true that features of the formation of the body are as perceptible and a consummation of nice skills and as there is possibility of direct intervention to control them at ease, not great for our mind - there is no perceptible existence to control them in a direct way - we need to control and measure them through our physical intelligence, feeling and skills. Now if outward impacts can influence our mind and all the tangible effects of the body and brain can motivate our cells and nerves, does it prove if we think - some chemical reactions are happenings for the outwards influences on the inner workings of the mind, can we bind our mind to a certain extent for this ? We can think - all the six enemies are at the centre of our subconscious mind - if we think some hormonal reactions happen for the workings of the excitements of the outward influences or the hormonal reaction are happenings by the outward influences igniting the mind and make the realization of it for its vibrancy and in both cases if some secretion of the chemicals or hormones are the main cause of it, then it is within our control to dominate them on check its activities. It is my belief that its control and its finer knots are within our scientific thoughts. My earnest request is to the Scientists \& Psychologist that for the balance on the control of the six enemies can they invent any special medicines without side effects. Is it possible to invent a new vaccine that can easily control our six enemies. So by controlling a generation or various generation, we can control this recklessness of human civilization. We should quicken our efforts in this respect through various researches and observations. Science will not fail in this respect because it has become successful in inventing life saving drugs for the fatal diseases. Meditation or Medication - can control this type of outbreak about the six inherent vices. If science can become successful in this invention, the world can get rid of this hellish condition and the planet will be a paradise for mankind. 